Vol IV. No.1, September 2019, hlm. 33- 43

Available online at www.jurnal.una.ac.id/indeks/jmp

\title{
KENDALI OPTIMAL PADA SISTEM PREY PREDATOR DENGAN PEMBERIAN MAKANAN ALTERNATIF PADA PREDATOR
}

\author{
Fitroh Resmi ${ }^{1}$ dan Subchan ${ }^{2}$ \\ ${ }^{1}$ JurusanMatematika,Fakultas MIPA, Universitas Billfath, Lamongan \\ ${ }^{2}$ JurusanMatematika,Fakultas MIPA, InstitutTeknologiSepuluhNopember (ITS) \\ Email: fitroh.resmi@billfath.ac.id
}

\begin{abstract}
This article discusses the predator prey system by providing alternative food to predators. Provision of alternative food aims to meet the food needs of predators. However, alternative foods require costs. To overcome this problem, it is necessary to control the amount of alternative feeding. Determination of optimal control using Pontryagin's Maximum Principle. Simulation results show that alternative feeding optimally can maximize the population of prey and predators at the end of time and minimize the costs due to alternative feeding.

Keywords : Pontryagin's Maximum Principle, Alternative food predators, Optimal control.
\end{abstract}

\begin{abstract}
Abstrak
Dalam artikel ini dibahas sistem prey predator dengan pemberian makanan alternatif pada predator. Pemberian makanan alternatif bertujuan untuk memenuhi kebutuhan makanan predator. Namun, pemberian makanan alternatif memerlukan biaya. Untuk mengatasi masalah tersebut, diperlukan adanya pengendalian terhadap jumlah pemberian makanan alternatif. Penentuan kendali yang optimal menggunakan Prinsip Maksimum Pontryagin. Hasil simulasi menunjukkan bahwa pemberian makanan alternatif secara optimal dapat memaksimumkan populasi prey dan predator di waktu akhir serta meminimumkan biaya akibat pemberian makanan alternatif.
\end{abstract}

Kata Kunci: Prinsip Maksimum Pontryagin, Prey Predator makanan Alternatif, Kendali Optimal.

\section{PENDAHULUAN}

Pada rantai makanan dikenal istilah prey dan predator. Prey merupakan suatu organisme yang dimakan atau dikenal dengan istilah mangsa. Sedangkan predator merupakan suatu organisme yang memakan, biasanya dikenal dengan istilah pemangsa. Hubungan dinamis antar prey dan predator sangat menarik untuk dipelajari dan menjadi salah satu topik yang sering dibahas di kalangan peneliti. Seperti yang dikerjakan oleh Arum Fitri Anisya dalam Tugas Akhirnya yang berjudul analisa kestabilan dan kendali optimal pada model pemanenan fitoplanktonzooplankton. Model yang digunakan terdiri dari satu prey dan predator.[5]Sedangkan Nabila Asyiqotur Rohmah dalam Tugas Akhirnya yang berjudul pengendalian populasi hama pada model mangsapemangsa dengan musuh alaminya, menggunakan model Lotka-Volterra dua prey dan satu predator. [4]

Dalam Tugas Akhir ini akan dibahas suatu sistem prey predator dimana predator diberikan makanan alternatif. Pemberian makanan 
Vol IV. No.1, September 2019, hlm. 33- 43

Available online at www.jurnal.una.ac.id/indeks/jmp

alternatif pada predator dilakukan karena dalam sistem prey predator tersebut, jumlah prey lebih sedikit dari pada jumlah predator. Sehingga kebutuhan makanan predator kurang terpenuhi.Pemberian makanan alternatif ini memungkinkan untuk diberikan kepada predator karena dalam rantai makanan, predator dapat memakan lebih sari satu jenis prey. Namun, pemberian makanan alternatif ini membutuhkan biaya, sehingga perlu ditentukan jumlah pemberian makanan alternatif yang optimal. Dalam menentukan jumlah pemberian makanan alternatif dapat menerapkan teori kendali optimal menggunakan Prinsip Maksimum Pontryagin. Dalam Tugas Akhir ini, pemberian makanan alternatif diasumsikan bersifat tidak dinamis. Dengan kata lain, makanan alternatif selalu tersedia untuk predator dengan jumlah sesuai dengan perhitungan dari kendali optimal.

Manfaat yang diharapkan dalam Tugas Akhir ini adalah diperolehnya pengetahuan untuk menerapkan teori kendali optimal menggunakan Prinsip Maksimum Pontryagin dalam sistem prey predator dengan pemberian makanan alternatif pada predator dan dapat dijadikan sebagai referensi dalam upaya mencegah terjadinya ketidakseimbangan ekosistem.

\section{Pertumbuhan Populasi}

Populasi adalah kumpulan individu dari suatu spesies yang sama yang menempati suatu tempat tertentu. Perubahan ukuran populasi pada periode waktu tertentu disebut dengan laju pertumbuhan populasi. Laju pertumbuhan dapat dimodelkan ke dalam suatu persamaan differensial yang dapat memprediksikan pertumbuhan suatu populasi. Sebagian besar model pertumbuhan makhluk hidup memiliki bentuk fungsi non linier. Ada beberapa model pertumbuhan makhluk hidup diantaranya model eksponensial dan model logistik. Model eksponensial yang sederhana dapat memberikan pendekatan yang sesuai untuk pertumbuhan hanya untuk periode awal karena model tersebut tidak memperhatikan adanya persaingan atas terbatasnya daya dukung lingkungan seperti makanan dan habitat. Sebaliknya model logistik secara realistis dan sederhana memperhatikan faktor daya dukung lingkungan (carrying capacity). [6]

\section{Sistem Dinamik}

Model matematika dari sistem dinamik prey predator adalah sebagai berikut [1] :

$$
\begin{aligned}
& \frac{d x}{d t}=r x\left(1-\frac{x}{k}\right)-\frac{\alpha x y}{1+x}-e_{1} x, \\
& \frac{d y}{d t}=\frac{\beta \alpha x y}{1+x}-m y-e_{2} y,(2.1) \\
& \text { dengan } \\
& \quad x=\text { populasi prey pada saat }
\end{aligned}
$$
waktu t waktu t

$y=$ populasi predator pada saat

$r=$ laju pertumbuhan intrinsik prey

$k$ = daya dukung lingkungan

$m=$ laju kematian alami predator

$\beta=$ laju konversi dari biomassa

prey ke biomassa

$$
\begin{aligned}
& \text { predator } \\
& \frac{\alpha x y}{1+x}=\text { fungsi respon predator }
\end{aligned}
$$

(Holling tipe II)

$$
e_{1}=\text { upaya pemanenan pada }
$$

prey

predator 
Vol IV. No.1, September 2019, hlm. 33- 43

Available online at www.jurnal.una.ac.id/indeks/jmp

Pada sistem (2.1) belum terdapat kondisi tambahan ketika predator diberikan makanan alternatif. Berikut ini model matematika dari sistem prey predator dengan pemberian makanan alternatif pada predator [1] :

$$
\begin{aligned}
& \frac{d x}{d t}=r x\left(1-\frac{x}{k}\right)-\frac{\alpha A x y}{1+x}-e_{1} x, \\
& \frac{d y}{d t}=\frac{\beta A \alpha x y}{1+x}+(1-A) y-m y- \\
& e_{2} y,(2.2)
\end{aligned}
$$

dimana A adalah konstanta yang menyatakan jumlah pemberian makanan alternatif dengan nilai $\mathrm{A}, 0<$ A $<1$.

Ketika $\mathrm{A}=0$ maka tidak terjadi interaksi antara prey dan predator. Interaksi hanya terjadi antara predator dengan makanan alternatif. Ketika A = 1 maka sistem (2.2) menjadi sama seperti sistem (2.1) dimana interaksi hanya terjadi pada prey dan predator dan tidak ada pemberian makanan alternatif. Ketika $0<\mathrm{A}<1$ maka predator tidak hanya berinteraksi dengan prey tetapi juga dengan predator.

\section{Fungsi Obyektif}

Dalam menentukan kendali optimal pada sistem prey predator dengan pemberian makanan alternatif pada predator, tujuan yang akan dicapai adalah memaksimalkan populasi prey dan predator dengan meminimumkan biaya akibat pemberian makanan alternatif. Sehingga model matematikanya adalah sebagai berikut [1] :

$$
\begin{gathered}
J(C)=\omega_{1} x(T)+\omega_{2} y(T) \\
-\omega_{3} \int_{0}^{T} C^{2} d t
\end{gathered}
$$

dengan

$$
\omega_{1}=\text { bobot massa prey saat waktu }
$$
tertentu $\omega_{2}=$ bobot massa predator saat waktu tertentu

$\omega_{3}=$ bobot fungsi biaya sepanjang interval $T$

$x(T)=$ populasi prey pada saat waktu tertentu

$y(T)=$ populasi predator pada saat waktu tertentu

$C=$ fungsi biaya akibat pemberian makanan alternatif

dimana $C=1-\mathrm{A}$

\section{Masalah Kendali Optimal}

Tujuan utama permasalahan kendali optimal adalah mencari nilai kendali $u(t)$ yang akan diproses dalam sistem dinamik dan memenuhi kendala fisik. Kemudian pada wakktu yang sama dapat ditentukan nilai optimum (maksimum atau minimum) yang sesuai dengan kriteria fungsi tujuan.

Pada umumnya, masalah kendali optimal dalam bentuk ungkapan matematik dapat diformulasikan sebagai berikut, dengan tujuan mencari kendali $u(t) \quad$ yang mengoptimalkan fungsi tujuan

$$
\begin{array}{r}
J(x)=S\left(x\left(t_{f}\right), t_{f}\right)+ \\
\int_{t_{0}}^{t_{f}} V(x(t), u(t), t) d t(2.3)
\end{array}
$$

dengan sistem dinamik yang dinyatakan oleh

$\dot{x}(t)=f(x(t), u(t), t)(2.4)$

dan kondisi batas

$$
x\left(t_{0}\right)=x_{0}, x\left(t_{f}\right)=x_{f}
$$

Fungsi tujuan $J$ pada persamaan di atas dinyatakan dalam bentuk Bolza. Jika $S=0$, maka disebut bentuk Lagrange. Sedangkan jika $\mathrm{V}=0$, maka dinamakan bentuk Meyer. [2]

\section{Prinsip Makismum Pontryagin}

Penyelesaian masalah kendali optimal dengan menggunakan metode 
Vol IV. No.1, September 2019, hlm. 33- 43

Available online at www.jurnal.una.ac.id/indeks/jmp

tidak langsung dilakukan dengan menyelesaikan kondisi perlu kendali optimal. Berdasarkan prinsip maksimum pontryagin, kondisi perlu dari masalah kendali optimal yang harus diselesaikan adalah persamaan stasioner, state dan costate serta kondisi transversality.

Langkah-penyelesaian dari masalah kendali optimal yang diformulasikan oleh persamaan (2.3)(2.5) adalah sebagai berikut [2]:

1. Bentuk Hamiltonian

$$
\begin{gathered}
H(x(t), u(t), \lambda(t), t) \\
=V(x(t), u(t), t)+ \\
\lambda^{\prime}(t) f(x(t), u(t), t)
\end{gathered}
$$

2. Memaksimumkan Hterhadap $u(t)$ yaitu dengan cara :

$$
\begin{aligned}
& \frac{\partial H}{\partial u}=0 \\
& u^{*}(t)=h\left(x^{*}(t), \lambda^{*}(t), t\right) .
\end{aligned}
$$

3. Dengan menggunakan $u^{*}(t)$ yang telah dihasilkan pada langkah 2 , akan didapatkan fungsi Hamilton baru yang optimal, $H^{*}(t)$, yaitu :

$$
\begin{aligned}
& H^{*}\left(x^{*}(t), u^{*}(t), \lambda^{*}(t), t\right) \\
= & H\left(x^{*}(t), \lambda^{*}(t), t\right)
\end{aligned}
$$

4. Selesaikan $2 \mathrm{n}$ persamaan state dan costate

$\dot{x}(t)=\frac{\partial H^{*}}{\partial \lambda}$ dan $\dot{\lambda}(t)=-\frac{\partial H^{*}}{\partial x}$

dengan kondisi batas yang diberikan oleh keadaan awal dan keadaan akhir yang disebut kondisi transversality, yaitu :

$$
\begin{aligned}
\left(H^{*}+\right. & \left.\frac{\partial S}{\partial t}\right)_{t_{f}} \delta t_{f} \\
& +\left(\left(\frac{\partial S}{\partial x}\right)_{*}\right. \\
& \left.-\lambda^{*}(t)\right)_{t_{f}}^{\prime} \delta x_{f} \\
& =0
\end{aligned}
$$

dengan $\mathrm{S}$ adalah bentuk Meyer dari fungsi tujuan $J, H$ adalah persamaan Hamiltonian, $\delta$ menunjukkan variasi dan tanda * menunjukkan keadaan saat variabel kontrolnya stasioner.

5. Subtitusi hasil-hasil yang diperoleh pada lagkah 4 ke dalam persamaan $u^{*}(t)$ pada langkah 2 untuk mendapatkan kendali yang optimal.

Dalam menentukan kondisi transversal yang sesuai terdapat macam-macam kondisi batas, yaitu :

1. Fix waktu akhir dan fix state akhir

$$
x\left(t_{0}\right)=x_{0}, x\left(t_{f}\right)=x_{f}
$$

2. Free waktu akhir dan fix state akhir

$$
\begin{aligned}
x\left(t_{0}\right) & =x_{0}, x\left(t_{f}\right) \\
& =x_{f},\left(H^{*}+\frac{\partial S}{\partial t}\right)_{t_{f}} \\
& =0
\end{aligned}
$$

3. Fix waktu akhir dan free state akhir

$$
x\left(t_{0}\right)=x_{0}, \lambda^{*}\left(t_{f}\right)=\left(\frac{\partial S}{\partial x}\right)_{* t_{f}}
$$

4. Free waktu akhir dan dependent free state akhir

$$
\begin{gathered}
x\left(t_{0}\right)=x_{0}, x\left(t_{f}\right)=\theta\left(t_{f}\right), \\
\left(H^{*}+\frac{\partial S}{\partial t}+\left(\left(\frac{\partial S}{\partial x}\right)_{*}\right.\right. \\
\left.\left.-\lambda^{*}(t)\right)^{\prime} \dot{\theta}\left(t_{f}\right)\right)_{t_{f}} \\
=0
\end{gathered}
$$

5. Free waktu akhir dan independent free state akhir

$$
\begin{aligned}
\delta x & \left(t_{0}\right)=x_{0} \\
\left(H^{*}+\frac{\partial S}{\partial t}\right)_{t_{f}} & =0,\left(\left(\frac{\partial S}{\partial x}\right)_{*}-\lambda^{*}(t)\right)_{t_{f}} \\
& =0
\end{aligned}
$$


Vol IV. No.1, September 2019, hlm. 33- 43

Available online at www.jurnal.una.ac.id/indeks/jmp

\section{METODE}

\section{Metode Forward Backward Sweep Runge Kutta Orde 4}

Salah satu penyelesaian persamaan differensial biasa secara numerik adalah dengan metode runge kutta orde 4. Syarat perlu untuk bisa menggunakan metode ini adlah adanya nilai awal. Jika dalam suatu sistem persamaan differensial terdapat satu persamaan yang diketahui nilai awal dan persamaan yang lain diketahui nilai akhir, maka metode yang tepat adalah forward backward sweep runge kutta orde 4. Alur pengerjaannya adalah menyelesaikan persamaan yang diketahui nilai awalnya terlebih dahulu secara forward, kemudian persamaan lainnya yang diketahui nilai akhir dikerjakan secara backward. Secara matematika dapat dituliskan sebagai berikut :[3]

Sistem persamaan diferensial

$$
\begin{aligned}
& \frac{d x}{d t}=f(t, x(t), u(t)), \quad x\left(t_{0}\right) \\
& =a \\
& \frac{d \sigma}{d t}=g(t, x(t), \sigma(t), u(t)), \quad \sigma\left(t_{f}\right) \\
& =b \\
& t_{0} \leq t \leq t_{f}
\end{aligned}
$$

Rumus runga kutta orde 4

a. Forward Sweep

$$
\begin{gathered}
x(t+h) \approx x(t)+\frac{h}{6}\left(k_{1}+2 k_{2}\right. \\
\left.+2 k_{3}+k_{4}\right)
\end{gathered}
$$

dimana

$$
\begin{gathered}
k_{1}=f(t, x(t), u(t)) \\
k_{2}=f\left(t+\frac{h}{2}, x(t)+\frac{h}{2} k_{1}, u(t)\right) \\
k_{3}=f\left(t+\frac{h}{2}, x(t)+\frac{h}{2} k_{2}, u(t)\right) \\
k_{4}=f\left(t+h, x(t)+h k_{3}, u(t)\right)
\end{gathered}
$$

b. Backward Sweep

$$
\begin{gathered}
\sigma(t-h) \approx \sigma(t)-\frac{h}{6}\left(k_{1}+2 k_{2}\right. \\
\left.+2 k_{3}+k_{4}\right)
\end{gathered}
$$

dimana

$$
\begin{gathered}
k_{1}=g(t, x(t), u(t)) \\
k_{2}=g\left(t-\frac{h}{2}, \sigma(t)-\frac{h}{2} k_{1}, u(t)\right) \\
k_{3}=g\left(t-\frac{h}{2}, \sigma(t)-\frac{h}{2} k_{2}, u(t)\right) \\
k_{4}=g\left(t-h, \sigma(t)-h k_{3}, u(t)\right)
\end{gathered}
$$

Dalam masalah kendali optimal, metode forward backward sweep runge kutta orde 4 ini dapat diterapkan. Dimana kita akan menyelesaikan persamaan state dan costate yang berbentuk persamaan differensial non linier untuk mendapatkan kendali yang optimal. Berikut ini langkah-langkah yang harus diikuti :

a. Langkah 1

Membagi interval sebanyak $\mathrm{N}$ subinterval. Sehingga state dan costate dapat didefinisikan sebagai suatu vektor : state $\vec{x}=$ $\left(x_{1}, \ldots, x_{N+1}\right) \quad$ dan $\quad$ costate $\vec{\sigma}=$ $\left(\sigma_{1}, \ldots, \sigma_{N+1}\right)$.

b. Langkah 2

Buat tebakan awal untuk kendali $\vec{u}$ sepanjang interval $t$.

c. Langkah 3

Gunakan nilai awal $x\left(t_{0}\right)=a$ dan nilai $\vec{u}$ untuk menyelesaikan persamaan state secara forward sweep.

d. Langkah 4

Gunakan nilai akhir $\sigma\left(t_{f}\right)=b$ dan nilai $\vec{x}, \vec{u}$ hasil dari langkah 3 untuk menyelesaikan persamaan costate secarabackward sweep.

e. Langkah 5

Perbarui nilai $\vec{u}$ dengan mensubtitusi nilai $\vec{x}$ dan $\vec{\sigma}$ yang baru ke dalam karakterisasi kendali optimal.

f. Langkah 6

Cek konvergensi. Jika nilai dari variabel-variabel dalam iterasi ini 
Vol IV. No.1, September 2019, hlm. 33- 43

Available online at www.jurnal.una.ac.id/indeks/jmp

dengan iterasi yang terakhir sama maka hasilnya adalah nilai yang sekarang didapatkan. Jika tidak, maka kembali ke langkah 3.

Untuk mengecek konvergensi banyak caranya, salah satunya :

$$
\frac{\|\vec{u}-\overrightarrow{\text { old } u}\|}{\|\vec{u}\|} \leq \delta
$$

dimana $\vec{u}$ adalah nilai $\vec{u}$ yang baru, sedangkan $\overrightarrow{\text { oldu }}$ adalah nilai $\vec{u}$ yang lama dan $\delta$ adalah konstanta real positif $(\delta>0)$.

\section{HASIL DAN PEMBAHASAN}

\section{Model Prey Predator dengan Pemberian Makanan Alternatif pada Predator}

Model dinyatakan dalam bentuk turunan terhadap waktu seperti yang telah ditunjukkan pada persamaan (2.2). Dimana populasi dibagi menjadi dua kelompok, yaitu populasi prey $x$ dan populasi predator $y$.Karena $x, y$ menyatakan jumlah, maka nilai $x, y$ positif.

a. Populasi Prey

$$
\frac{d x}{d t}=r x\left(1-\frac{x}{k}\right)-\frac{\alpha A x y}{1+x}-e_{1} x,
$$

menyatakan bahwa perubahan ukuran populasi prey pada selang waktu $\mathrm{t}$ dipengaruhi oleh laju pertumbuhan intrinsik prey yang mengakibatkan populasi bertambah, persaingan sesama prey akibat keterbatasan daya dukung lingkugan mengakibatkan populasi berkurang, interaksi antara prey dan predator (predator memakan prey) serta upaya pemanenan pada preyyang mengakibatkan populasi berkurang. Oleh karena itu, nilair $, k, \alpha, e_{1}$ selalu positif. b. Populasi Predator

$$
\begin{gathered}
\frac{d y}{d t}=\frac{\beta A \alpha x y}{1+x}+(1-A) y-m y \\
-e_{2} y,
\end{gathered}
$$

Menyatakanbahwaperubahanukur anpopulasipredatorpadaselangwa $\mathrm{ktu} \mathrm{t}$ dipengaruhi oleh interaksi antara prey dan predator (predator memakan prey) mengakibatkan populasi bertambah, pemberian makanan alternatif yang juga menambah populasi, sedangkan kematian alami dan upaya pemanenan pada predator mengakibatkan berkurangnya populasi. Oleh karena itu, $\quad \alpha, e_{2}, m$ bernilai positif. $\beta<1$ karena tidak semua biomassa dari prey masuk ke biomassa predator.

\section{Daerah Penyelesaian Model}

Sistem(2.2) mempunyai penyelesaian pada kuadran positif $R_{+}^{2}$ yang dinyatakan pada teorema berikut ini :

Teorema 1.Jika parameter $A$ dan $e_{2}$ memenuhi kondisi $e_{2}+A>1-$ $m$, maka semua penyelesaian dari system (2.2) berada pada kuadran positif $R_{+}^{2}$.

Bukti: Didefinisikan $\Omega(t)=x+\frac{y}{\beta}$. Kemudian didapatkan $\frac{d \Omega}{d t}=$ $r x\left(1-\frac{x}{k}\right)-e_{1} x+\frac{\left(1-A-m-e_{2}\right) y}{\beta}$.

Sehingga

$$
\begin{aligned}
\frac{d \Omega}{d t}+\left(e_{2}+m\right. & +A-1) \Omega \\
& =-\frac{r}{k}\left(x-\frac{k}{2 r} \mu\right)^{2} \\
& +\frac{k}{4 r} \mu^{2} \\
\leq & \frac{k}{4 r} \mu^{2} .
\end{aligned}
$$


Vol IV. No.1, September 2019, hlm. 33- 43

Available online at www.jurnal.una.ac.id/indeks/jmp

dimana $\mu=r-e_{1}+e_{2}+m+A-$ 1dan misalkan $W=\frac{k}{4 r} \mu^{2}$, maka persamaanya menjadi

$$
\frac{d \Omega}{d t}+\left(e_{2}+m+A-1\right) \Omega \leq W .
$$

Penyelesaian umum dari persamaan differensial linier tingkat 1 yaitu :

$$
\begin{aligned}
& \Omega(t)=\frac{W}{\left(e_{2}+m+A-1\right)} \\
&+C e^{-\left(e_{2}+m+A-1\right) t} . \\
& \text { Untuk } t \rightarrow \text { omakalim }_{t \rightarrow \infty} \Omega(t)=
\end{aligned}
$$
$\frac{W}{\left(e_{2}+m+A-1\right)}$.

Dari hasil ini dapat disimpulkan bahwa

$$
0<\Omega(t) \leq \frac{W}{\left(e_{2}+m+A-1\right)}
$$

Yang artinya sistem pada persamaan (2.2)mempunyai penyelesaian pada kuadran positif $R_{+}^{2}$ jika $e_{2}+A-1+$ $m>0$ ataudengan kata lain $e_{2}+A>$ $1-m$.

\subsection{Penyelesaian Kendali Optimal}

Diberikan fungsi obyektif

$$
\begin{gathered}
J(C)=\omega_{1} x(T)+\omega_{2} y(T) \\
-\omega_{3} \int_{0}^{T} C^{2} d t
\end{gathered}
$$

Dengan system dinamik :

$$
\begin{gathered}
\frac{d x}{d t}=r x\left(1-\frac{x}{k}\right)-\frac{\alpha(1-C) x y}{1+x} \\
\frac{d y}{d t}=\frac{\beta(1-C) \alpha x y}{1+x}+C y-m y \\
-e_{2} y
\end{gathered}
$$

Yang memiliki syarat batas:

$$
\begin{gathered}
x(0)=x_{0}, y(0)=y_{0}, \\
C_{\text {min }} \leq C(t) \leq C_{\text {max }} .
\end{gathered}
$$

Untuk mencari kendali optimal, langkah pertamanya adalah membentuk Hamiltonian.

$$
\begin{gathered}
H\left(x(t), y(t), C(t), \sigma_{1}(t), \sigma_{2}(t)\right) \\
=-\omega_{3} C^{2}+
\end{gathered}
$$

$$
\begin{gathered}
\sigma_{1}\left(\begin{array}{c}
r x\left(1-\frac{x}{k}\right)- \\
\frac{\alpha(1-C) x y}{1+x}-e_{1} x
\end{array}\right)+ \\
\sigma_{2}\left(\begin{array}{c}
\frac{\beta(1-C) \alpha x y}{1+x}+C y- \\
m y-e_{2} y
\end{array}\right) .
\end{gathered}
$$

Kemudian menentukan kondisi stasioner dari Hamiltonian:

$$
\begin{aligned}
\frac{\partial H}{\partial C}=-2 \omega_{3} C & +\frac{\alpha \sigma_{1} x y}{1+x}-\frac{\alpha \beta \sigma_{2} x y}{1+x} \\
& +\sigma_{2} y=0
\end{aligned}
$$

Didapatkan kendali optimal $C^{*}(t)=$ $\frac{\frac{\alpha \sigma_{1} x y}{1+x}-\frac{\alpha \beta \sigma_{2} x y}{1+x}+\sigma_{2} y}{2 \omega_{3}}$.

Karena kendalinya terbatas maka :

$C^{*}(t)$

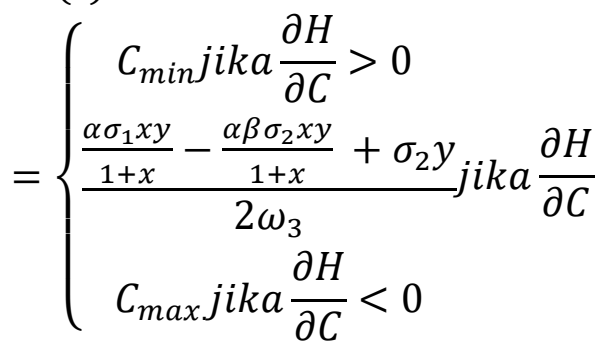

$$
\begin{aligned}
& =0
\end{aligned}
$$

Kemudian menentukan persamaan state dan costate :

a. Persamaan state :

$$
\begin{array}{r}
\dot{x}(t)=\frac{\partial H}{\partial \sigma_{1}}=r x\left(1-\frac{x}{k}\right) \\
-\frac{\alpha(1-C) x y}{1+x} \\
-e_{1} x \\
\dot{y}(t)=\frac{\partial H}{\partial \sigma_{2}}=\frac{\beta(1-C) \alpha x y}{1+x} \\
+C y-m y-e_{2} y
\end{array}
$$

b. Persamaan costate :

$$
\begin{gathered}
\dot{\sigma}_{1}(t)=-\frac{\partial H}{\partial x} \\
=-\left(\begin{array}{c}
\sigma_{1}\left(r\left(1-\frac{2 x}{k}\right)-\frac{\alpha(1-C) y}{(1+x)^{2}}-e_{1}\right)+ \\
\sigma_{2} \frac{\beta(1-C) \alpha y}{(1+x)^{2}}
\end{array}\right)
\end{gathered}
$$


Vol IV. No.1, September 2019, hlm. 33- 43

Available online at www.jurnal.una.ac.id/indeks/jmp

$$
\begin{gathered}
\dot{\sigma}_{2}(t)=-\frac{\partial H}{\partial y} \\
=-\left(\begin{array}{c}
-\sigma_{1}\left(\frac{\alpha(1-C) x}{1+x}\right)+ \\
\sigma_{2}\left(\frac{\beta(1-C) \alpha x}{1+x}+C-m-e_{2}\right)
\end{array}\right)
\end{gathered}
$$

Karena system memiliki fix di waktu akhir dan free pada state akhir maka terdapat kondisi tambahan (kondisi transversality) yaitu :

$$
\begin{aligned}
& \sigma_{1}(T)=\left(\frac{\partial S}{\partial x}\right)_{* T}=\omega_{1} \\
& \sigma_{2}(T)=\left(\frac{\partial S}{\partial y}\right)_{* T}=\omega_{2}
\end{aligned}
$$

Karena persamaan state dan costate memiliki bentuk non linier sehingga sulit untuk diselesaikan secara analitik makadiselesaikan secara numerik.

\subsection{Penyelesaian Numerik}

Penyelesaian secara numerik menggunakan metode forward backward sweep rungekutta orde 4. Hal ini dilakukan karena persamaan statenya diketahui nilai awal dan persamaan costate diketahui nilai akhir.Secara umum persamaan state dan costate dapat dituliskan menjadi :

$$
\begin{aligned}
& \quad \frac{d x}{d t}= \\
& f_{1}(x(t), C(t), y(t)), x(0)=x_{0} \\
& \quad \frac{d y}{d t}=f_{2}(x(t), C(t), y(t)), y(0) \\
& \quad=y_{0}
\end{aligned}
$$

Kemudian mengikuti langkahlangkah forward backward sweep rungekutta orde 4:

a. Langkah 1

Interval waktu $\mathrm{t}=[0, \mathrm{~T}]$ dibagi sebanyak N subinterval. Sehingga state dancostate dapat didefinisikan sebagai suatu vektor

$$
\begin{aligned}
& : \vec{x}=\left(x_{1}, \ldots, x_{N+1}\right), \vec{y}= \\
& \left(y_{1}, \ldots, y_{N+1}\right), \\
& \quad \overrightarrow{\sigma_{1}}=\left(\sigma_{1.1}, \ldots, \sigma_{1 . N+1}\right), \overrightarrow{\sigma_{2}} \\
& \quad=\left(\sigma_{2.1}, \ldots, \sigma_{2 . N+1}\right) .
\end{aligned}
$$

Artinya terdapat $\mathrm{N}+1$ titik di sepanjang waktu t. Dan didapatkan selisih antara setiap titiknya $\mathrm{h}=\mathrm{T} / \mathrm{N}$.

b. Langkah2

Memberikan nilai tebakan awal yaitu mengasumsikan nilai awal control $\vec{C}$ nol sepanjang interval $t$ untuk mengawali iterasi.

c. Langkah 3

Menggunakan nilaiawal $x(0)=$ $x_{0}$, dan $y(0)=$ $y_{0}$, sertanilaitebakan $\vec{C} \quad$ untuk menyelesaikan persamaan state secara forward sweep (maju).

d. Langkah 4

Menggunakan nilai akhir $\sigma_{1}(T)=$ $\omega_{1}, \sigma_{2}(T)=\omega_{2}$, nilai tebakan awal $\vec{C}$ serta hasil dari forward sweep $\vec{x}, \vec{y}$ untuk menyelesaikan persamaan costate secara backward sweep.

e. Langkah 5

Memperbarui nilai $\vec{C}$ dengan mensubtitusi nilai $\vec{x}, \vec{y}, \overrightarrow{\sigma_{1}}, \overrightarrow{\sigma_{2}}$ yang baru ke dalam karakterisasi kendali optimal. Dalam hal ini $C=\min (C \max , \max (C \operatorname{sig}, C \min ))$.

f. Langkah 6

Cek konvergensi. Didefinisikan nilai oldC, oldx, oldy, oldsigmal, oldsigma2 masing-masing sebagai nilai kontrol, state dan costate 
Vol IV. No.1, September 2019, hlm. 33- 43

Available online at www.jurnal.una.ac.id/indeks/jmp

yang lama. Sedangkan $C, x, y$, sigmal, sigma2 masing-masing adalah nilai kontrol, state dan costate yang baru. Jika minimal dari nilai-nilai konvergensi $C, x$, $y$, sigmal, sigma $2 \geq 0$ maka nilai yang optimal adalah $C, x, y$, sigmal, sigma2yang sekarang. Jika tidak, maka nilai $C, x, y$, sigmal, sigma2yang sekarang disimpan dengan nama old $C$, oldx, oldy, old sigma1, oldsigma2 dan kembali ke langkah 3.

\subsection{Analisa dan Hasil Simulasi}

Pada simulasi ini dibuat 3 kondisi. Yang pertama ketika tanpa kendali dimana predator tidak diberikan makanan alternatif $(\mathrm{C}=0)$, yang kedua ketika tanpa kendali dimana predator diberikan makanan alternatif secara penuh $(\mathrm{C}=1)$ dan yang ketigaketika dengan kendali dimana predator tidak diberikan makanan alternatif secara penuh $\quad\left(C_{\min } \leq C(t) \leq C_{\max }\right)$. Dengan $C_{\text {min }}=0.17, C_{\text {max }}$.

0.4.Berikutini parameter-parameter yang diberikan : $r=2, k=10, \alpha=$ $0.8, \beta=0.9, e_{1}=1.28, e_{2}=0.55, m$ $=0.1$. Dan bobot $\omega_{1}=1, \omega_{2}=$ $1, \omega_{3}=0.5$. Kemudian nilai awal $x(0)=1, y(0)=1.5$. Parameterparameter ini merujuk pada referensi [1]. Simulasi untuk kondisi ketika tanpa kendali menggunakan Runge Kutta orde 4 dan untuk kondisi dengan kendali menggunakan metode backward forward Runge Kutta orde 4.

\subsubsection{Pertumbuhan Populasi Prey}

Pertumbuhan populasi prey di semua kondisi meningkat. Hal ini terjadi karena ketika $\mathrm{C}=0$, faktor laju pertumbuhan intrinsik dan daya dukung lingkungannya lebih besar dari pada faktor predasi dari predator dan faktor upaya pemanenan. Sehingga prey dapat tumbuh dengan baik karena masih didukung oleh tersedianya logistik dan ruang untuk hidup. Sedangkan ketika $\mathrm{C}=1$, pertumbuhannya meningkat dengan cepat. Hal ini terjadi karena tidak adanya laju predasi predator ke prey serta lajupertumbuhan intrinsik dan kapasitas daya dukung lingkungan yang besar.

Ketika $C_{\min } \leq C(t) \leq C_{\max }$. terlihat bahwa pertumbuhan populasi prey meningkat, walaupun tidak terlalu signifikan. Hal ini terjadi karena adanya faktor predasi dari predator

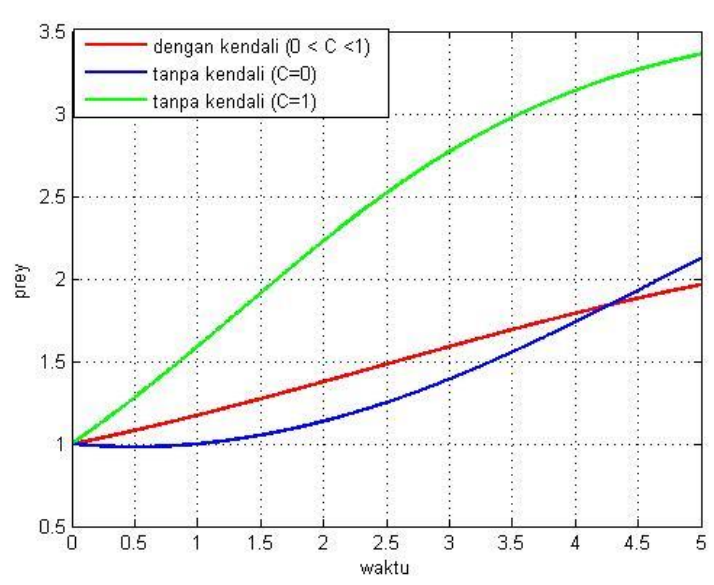

Gambar2. Grafik prey di semua kondisi serta adanya faktor pemberian makanan alternatif pada predator.

\subsubsection{Pertumbuhan Populasi Predator}

Berbeda dengan prey, grafik pertumbuhan populasi predator terlihat bervariasi seperti yang ditunjukkan oleh Gambar 4.2. Ketika $\mathrm{C}=0$, pertumbuhan predator menurun. Hal ini terjadi karena jumlah prey yang sedikit dari pada predator mengakibatkan kebutuhan predator kurang terpenuhi. Selain itu juga terdapat faktor kematian alami 
Vol IV. No.1, September 2019, hlm. 33- 43

Available online at www.jurnal.una.ac.id/indeks/jmp

predator serta upaya pemanenan terhadap predator.

Ketika $\mathrm{C}=1$, pertumbuhan predator naik karena predator tidak dipengaruhi oleh daya dukung lingkungan sehingga pertumbuhannya meningkat secara eksponensial serta adanya faktor pemberian makanan alternatif.

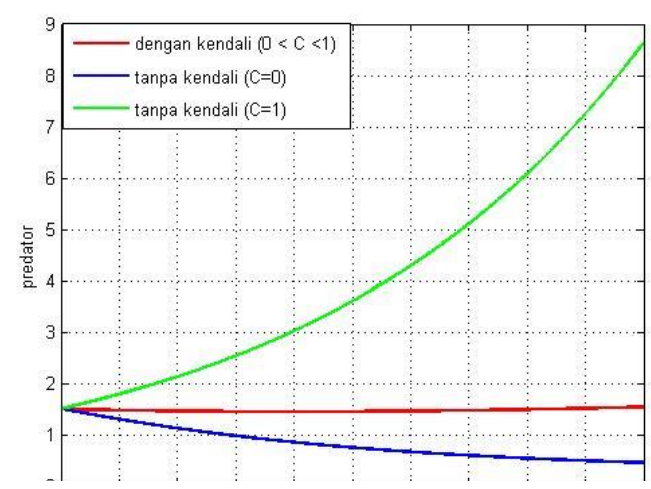

Gambar4. Grafik predator di semua kondisi

Kemudian ketika $C_{\min } \leq C(t) \leq$ $C_{\text {max. }}$ pertumbuhan populasi predator sempat mengalami penurunan hingga waktu 2,035 dengan waktu 2,035 dengan jumlah predator 1,4431. Kemudian jumlahnya tetap hingga waktu 2,039. Setelah itu mengalami peningkatan pada waktu 2,04 dengan jumlah predator 1,4432 hingga waktu 5 dengan jumlah predator 1,5340 . Hal ini terjadi karena pada awalnya predator mengalami kesulitan untuk memangsa prey karena jumlah prey yang sedikit.

\subsubsection{Jumlah Pemberian Makanan Alternatif}

Untuk mendapatkan populasi prey dan predator yang maksimal maka pemberian makanan alternatif pada predator harus sesuai dengan grafik kendali optimal seperti yang bditunjukkan pada Gambar3.

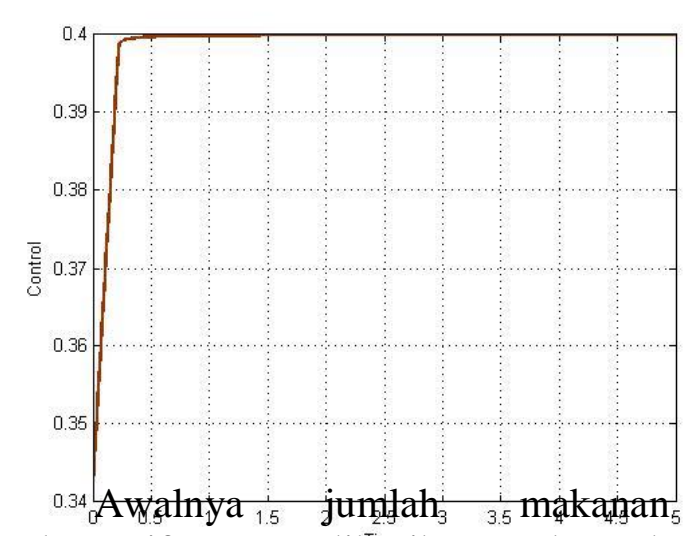
alternatif yang diberikan sebanyak 0,342 , kemudian berangsur meningkat hingga waktu 2,245. Pemberian makanan sejumlah 4 diberikan hingga

Gambar3. Grafik kendali optimal dalam sistem prey predator dengan pemberian makanan alternatif didapatkan bahwa biaya yang dikeluarkan saat diberikan makanan alternatif secara optimal nilainya jauh lebih kecil dari pada saat diberikan makanan alternatif secara penuh $(0,39$ $<2,5)$. Dan jumlah populasi prey dan predator di waktu akhir saat diberikan makanan alternatif secara optimal, nilainya jauh lebih besar dari pada saat tidak diberikan makanan alternatif $(3,4977>2,5716)$.

\section{SIMPULAN}

Berdasarkan analisi dan pembahasan yang telah disajikan pada bab sebelumnya, dapat disimpulkan beberapa hal sebagai berikut :

1. Dengan menerapkan teori kendali optimal menggunakan Prinsip Maksimum Pontryagin diperoleh pengendali optimal dalam sistem prey predator dengan pemberian makanan alternatif pada predator pada selang waktu $0<\mathrm{t}<5$ sebesar $0,342<\mathrm{C}<0,4$.

2. Dengan pemberian makanan alternatif secara optimal dapat memaksimumkan populasi prey dan predator serta meminimumkan biaya akibat pemberian makanan alternatif . 
Vol IV. No.1, September 2019, hlm. 33- 43

Available online at www.jurnal.una.ac.id/indeks/jmp

Didapatkan jumlah prey di waktu 5 sebesar 1,9637 dan jumlah predator di waktu 5 sebesar 1,534. Sedangkan biaya yang harus dikeluarkan akibat pemberian makanan alternatif selama waktu 5 sebesar 0,39.

\section{SARAN}

Adapun saran dari Tugas Akhir ini adalah untuk penelitian selanjutnya dapat dianalisa kestabilan pada sistem prey predator dengan pemberian makanan alternatif pada predator dan

\section{DAFTAR RUJUKAN}

[1] Kar, T.K. dan Ghosh, B. (2012). "Sustainability and Optimal Control of an Exploited Prey and Predator System Through Provision of Alternative Food to Predator".Elsevier.

BioSystems.Hal.220-232

[2] Naidu, S. D. (2002).Optimal Control System. USA: CRC Press LLC.

[3] Lenhart, S. dan Workman T. John. (2007). Optimal Control Applied toBiological Model. New York : Taylor and Francis Group.

[4] Rohmah, N.A. (2013). "Pengendalian Populasi Hama juga dapat membandingkan hasil penyelesaian numerik antar Runge Kutta orde 4 dengan Metode Beda Hingga. Selain itu, dapat dianalisa pula banyak sedikitnya upaya pemanenan agar dapat lebih memaksimalkan jumlah prey dan predator di waktu akhir. Dengan kata lain, yang menjadi kendali tidak hanya jumlah pemberian makanan tetapi juga upaya pemanenan. pada Model Mangsa-Pemangsa dengan Musuh Alaminya". Tugas Akhir Jurusan Matematika ITS Surabaya

[5] Anisya, A.F. (2013). "Analisa Kestabilan dan Kendali Optimal pada Model Pemanenan Fitoplankton-Zooplankton". Tugas Akhir Jurusan Matematika ITS Surabaya

[6] Alvendar, J dan Baqi, A.I. 2012."Model Pemanenan Logistik dengan Daya Dukung Bergantung Waktu”. Jurnal Matematika UNAND. No 2. Vol 1. Hal 60-65 